\title{
The Effect Of Using Colored Clip Media On Student Learning Outcomes In Mathematics Learning Class Iii Sd Inpres Btn Ikip I Kota Makassar
}

\author{
Amrah $^{1}$, Bahar $^{2}$, Rika Bonita ${ }^{3}$ \\ \{baharbethatwins@gmail.com ${ }^{1}$,amrahpgsd@gmail.com ${ }^{2}$, rikabonita10@yahoo.com ${ }^{3}$ \} \\ ${ }^{1,2,3}$ Universitas Negeri Makassar, Indonesia
}

\begin{abstract}
This study aims to describe the use of colored pieces of media and learning outcomes and determine their effect on Mathematics Subjects of Class III SD Inpres BTN IKIP I Makassar City. In this study using a quantitative approach, as for the type of research used is experimental research. The population in this study was the whole class III using the sampling method that is simple random sampling where class III A numbered 34 students and class III B totaled 32 students with a total sample of 66 students. Data were collected using research instruments in the form of test questions. The data analysis technique used is the Independent Sample t-test. The results showed that there was an influence of the use of colored pieces of media on student learning outcomes in mathematics class III SD Inpres BTN IKIP I Makassar City.
\end{abstract}

Keywords: Learning outcomes, Color pieces media

\section{Introduction}

Mathematics is one of the subjects that has an important role in education. Studying mathematics is one means of scientific thinking and logical effort. Improving the quality of human resources. In real life, mathematics is used to solve everyday problems. Mathematics is also a source of various sciences. In addition, Mathematics also plays an important role in the development of various sciences, namely being able to practice reasoning, think critically and logically, and train innovative patterns in solving problems faced. This is in accordance with the objectives of mathematics education according to the 2006 curriculum in general, namely to train thinking systematically, logically, critically, creatively, and consistently (Depdiknas, 2006). Specifically, the goal is for students to have the ability: (1) understand, explain, and apply concepts and problem solving, (2) use reasoning, generalize, construct evidence, and explain ideas, (3) solve problems, (4) be able to communicate problems, and (5) appreciates the usefulness of mathematics (Permendiknas No. 22 of 2006). Based on the above objectives, Mathematics is given to equip students so that students have these abilities, therefore, the government prepares Basic Mathematics Competency and Competency Standards listed in the Minister of National Education Regulation No. 22 of 2006 as a foundation in learning mathematics (BSNP, 2006 Content Standards).

Mathematics learns about problem solving and reasoning that are closely related to numbers, geometry, and measurement, and data processing. In its application in elementary schools, mathematics is expected to foster critical thinking, logical attitudes, and also students' creative attitudes. In line with this, Lestari (2015) states that learning mathematics now aims to develop and practice problem solving skills. 
According to Susianto (2017) states that the basics of mathematics taught in elementary schools make students complain a lot about the difficulty of integer materials, especially in addition and subtraction. The difficulty of the material might be the lack of awareness of educators using teaching aids that are in accordance with integer operating material, which should have been using teaching aids but the educator does not use teaching aids or using teaching aids but not in accordance with the material being taught.

One of the efforts of teachers in creating pleasant learning conditions is the optimal use of learning media. The use of media in learning is to be able to bridge between abstract mathematical concepts to be more concrete, so students can understand what is presented by the teacher (Almira: 2014). For this reason, the use of media in the learning process is indispensable for the optimal achievement of learning objectives. By using the media, students will more easily understand the concepts learned, because learning involves physical and mental activities by seeing, feeling, and manipulating teaching aids that are in line with the characteristics of elementary school students who have a strong curiosity and are interested in exploring situations in around them with feelings of pleasure and excitement

Media that can be applied to integer material has many variations including number lines, umath cards, and colored chip media. The number line is a concrete media made of boards, plywood, and so on which have points with equal distance and each point contains numbers arranged with the number 0 (zero) located at the point located in the middle and the Umath card is a card made using help corel draw application that contains integer operation problems. the number of cards used on this Umath card is 100 cards, consisting of 76 ordinary cards or question cards that have the results of operations between 0 to 9 , and 24 action cards consisting of, 8 Draw cards, 8 Reverse cards, and 8 cards Skip While colored chip media is a learning medium that has two sides with different colors as a differentiator of negative numbers and positive numbers so that colored media pieces can be taught in the addition and subtraction of integer operations. Based on the three media, the researchers chose colored chip media in the study because the media because colored chip media have bright colors, which can distinguish positive integers and negative integers, besides that colored chip media also have varying degrees of difficulty and are safe and not easily damaged. So that the application of the use of colored pieces of media can improve student learning outcomes in mathematics

Based on the results of preliminary observations made on February 4 and 08, 2019, the authors obtained information that the subjects that were less liked were mathematics because they contained numbers and symbols that were not understood by students. One material that is less favored is the addition and subtraction of numbers, especially to integers. Besides the homeroom teacher revealed that mathematics is a subject with poor learning outcomes, this is because students tend to be less enthusiastic about these subjects. At the time of the learning process the teacher also did not vary using instructional media as a tool to arouse student learning enthusiasm.

Based on these problems the researchers offered the right media to be used in integer material, namely colored chip media. Colored chip media is one of the media which is flat and has two sides. Each side has a different color. It aims to give symbols to negative integers or positive integers, this agreement can be done before learning begins. In addition, colored pieces of media can be brought under any direction because of light and small-sized media, colored chips have bright colors so that they can encourage students' enthusiasm for learning. Sri Rohartati in 2017 published in her journal with the title "The application of colored pieces of media to the learning outcomes of students in mathematics in elementary schools Sukasari Kec. Cipatat ", shows that learning outcomes have increased significantly. Then based on the results of research written by Luluk Alvia in 2017 showed that the development of the color 
learning media chips on the addition and subtraction material to improve mathematics learning outcomes of grade I students at MIN Sukosewu Blitar also increased.

\section{Methodology of Research}

This study uses a quantitative approach. In this approach, the data will be analyzed quantitatively / statistically to test the hypotheses that have been proposed. The type of research used is experimental research. The type of experimental research used is TrueExperimental Design. This research is quasi experiment to get a picture of increasing student learning outcomes by comparing the pretest and posttest scores between the control class and the experimental class. The research design used in this study is the pre-test post-test control group design. This design involves two classes, namely the experimental class and the control class. Before the treatment is done in both classes, a pretest is given first, that is to know the students' initial abilities. Furthermore, the experimental class was given treatment using colored chip media, while the control class without using colored chip media. After being given treatment, both classes were given a posttest to determine the student's final ability.

\section{Results}

The use of colored pieces of media in Mathematics in experimental class has a positive influence on improving student mathematics learning outcomes. This is proven by the results of observations that have been made during the learning process. The results of these observations can be seen in the following table:

Table 7. Description of the Practice Sheet Realistic Mathematics Education Approach

\begin{tabular}{rlccc}
\hline Number & Observed Activities & \multicolumn{3}{c}{ Skor } \\
\cline { 3 - 5 } & & Meeting 1 & Meeting 2 & Meeting 3 \\
\hline 1. & Opener & 2 & 3 & 2 \\
\hline 2. & $\begin{array}{l}\text { Submission of Material } \\
\text { Using colored pieces of } \\
\text { media }\end{array}$ & 2 & 3 & 3 \\
\hline 3. & $\begin{array}{l}\text { Student Discussion } \\
\text { Process }\end{array}$ & 2 & 1 & 3 \\
\hline 4. & Feedback & 2 & 1 & 2 \\
\hline 5. & Closing & 2 & 3 & 3 \\
\hline & Total & 10 & 11 & $86,67 \%$ \\
\hline Percentage of Total & Kategori & Effective & Effective & Very Effective \\
\hline
\end{tabular}

This shows that the implementation of learning using colored pieces of media took place effectively because the percentage categories for each meeting increased.

Student mathematics learning outcomes used before treatment namely pretest and after treatment were measured using posttest. Pretest and posttest are multiple choice questions consisting of 23 questions. Based on the analysis results obtained as follows: 
Table 8. Summary of Research Results

\begin{tabular}{ccccc}
\hline Statistik & $\begin{array}{c}\text { Pretest } \\
\text { Eksperimen }\end{array}$ & $\begin{array}{c}\text { Pretest } \\
\text { Kontrol }\end{array}$ & $\begin{array}{c}\text { Posttest } \\
\text { Eksperimen }\end{array}$ & $\begin{array}{c}\text { Posttest } \\
\text { Kontrol }\end{array}$ \\
\hline Mean & 17.2059 & 17.9375 & 19.5588 & 17.4688 \\
\hline Median & 17 & 18 & 20 & 17,5 \\
\hline Mode & 17 & 18 & 20 & $17,18,19$ \\
\hline Std. Deviation & 1.64739 & 1.89970 & 1,65495 & 1,64580 \\
\hline
\end{tabular}

If the pretest and posttest scores of mathematics learning outcomes are grouped in intervals of frequency distribution and percentage of mathematics learning outcomes categories, the pretest results of the experimental class are in the sufficient category, while the posttest results are in the category and the controls are in the good category. The results of the control class pretest were in the moderate category while the posttest in the control category was sufficient.

Hypothesis testing conducted aims to determine differences in student learning outcomes between the experimental class and the control class before being treated. The following are the results of the Independent Sample t-Test in the pretest and posttest values of the experimental class and the control class.

Table 9. Test Results of Independent Sample T-Test Pretest and Posttest Experiment class and Control class

\begin{tabular}{lcl}
\multicolumn{1}{c}{ Data } & Sig $_{\text {hitung }}$ & \multicolumn{1}{c}{ Information } \\
\hline $\begin{array}{l}\text { Pretest } \text { Experiment and } \\
\text { Pretest } \text { Control }\end{array}$ & 0,969 & $\begin{array}{l}0,969>0,05=\text { no } \\
\text { difference }\end{array}$ \\
\hline $\begin{array}{l}\text { Posttest } \text { Experiment and } \\
\text { Pretest } \text { Control }\end{array}$ & 0,000 & $\begin{array}{l}0,000<0,05=\text { There is a } \\
\text { difference }\end{array}$ \\
& & \\
\hline
\end{tabular}

Based on the table it is known that there is no significant difference in mathematics learning outcomes between the experimental class and the control class before being given treatment. While in the experimental and control class posttests it was seen that there were significant differences in the mathematics learning outcomes of the class being taught using colored chip media and classes without using colored chip media.

Based on hypothesis testing with inferential statistics shows that there is a significant influence on student learning outcomes after the use of colored pieces of media in the learning process. The results of hypothesis testing are carried out in two ways, namely comparing ttable and tcount and comparing probability values. Statistical results using manual calculations for independent sample t test combined with the help of the SPSS 20.0 program obtained the value of ttable with df $(64)=2.069$ while the t-test student answer results 5,141 , t-count $(5,141)>\mathrm{t}$-table $(2,069)$ so that Ho is rejected and Ha accepted without seeing positive (+) or negative (-). Whereas by comparing the probability value, the significance value obtained from the results of the post-test learning test of the experimental class and the control class, the probability value of $0,000<0.05$ means that Ho is rejected and $\mathrm{Ha}$ is accepted. So it can be concluded that there is an influence of the use of colored pieces of media on student learning outcomes in class III SD Inpres BTN IKIP I Makassar City 


\section{Conclusion}

Based on the results of the study showed that student learning outcomes in the experimental class improved more than student learning outcomes in the control class. This can be seen with the post-test scores in the experimental class in the high category while in the control class in the low category. There is an influence of the use of colored pieces of learning media. This is because there is a significant difference between the experimental class using colored chip learning media and the control class without using colored chip learning media. This is because the probability value is smaller than 0.05 .

\section{References}

Amir, Almira. 2014. Pembelajaran Matematika SD dengan Menggunakan Media Manipulatif. Jurnal Forum Paedagogik. Vol. VI. No. 01 Januari 2014

Alvia, Luluk. 2017. Pengembangan Media Pembelajaran Keping Warna pada Materi Penjumlahan dan Pengurangan untuk Meningkatkan Hasil Belajar Matematika Siswa Kelas I Di MIN Sukosewu Blitar. Skripsi. Malang: Program Study Pendidikan Guru Madrasah Ibtidayah Fakultas Tarbiyah Dan Keguruan Universitas Islam Negeri Maulana Malik Ibrahim Malang.

BSNP. 2006. Standar Isi Untuk Satuan Pendidikan Dasar dan Menengah. Jakarta: Badan Standar Nasional Pendidikan.

Lestari, Lesta dan Sofyan, Dedi. 2014. Perbandingan Kemampuan Pemecahan Masalah Siswa dalam Matematika antara yang Mendapat Pembelajaran Matematika Realistik (Pmr) dengan Pembelajaran Konvensional (Penelitian Eksperimen di Kelas VIII Sekolah Menengah Pertama Negeri Satu Sukawening). Jurnal Pendidikan Matematika. Vol. 3, Nomor 2, Mei 2014.

Rohartati, Sri. 2017. Penerapan Media Keping Berwarna terhadap Hasil Belajar Peseta Didik pada Mata Pelajaran Matematika di Sekolah Dasar (Studi Eksperimen pada Bilangan Bulat di Kelas IV SDN Sukasari Kec. Cipatat. Jurnal penjaminan mutu. Vol. 3, Nomor 2 Agustus 2017.

Susianto, Heri. 2017. Penerapan Alat Peraga Keping Berwarna untuk Meningkatkan Hasil Belajar Penjumlahan dan Pengurangan Bilangan Bulat. Jurnal Riset dan Konseptual. Vol. 2 Nomor 1, Februari 2017 